\title{
Hambatan Epistemologi Peserta Didik dalam Menyelesaikan Aritmatika Sosial Berdasarkan Gaya Belajar dan Perbedaan Gender
}

\author{
Fauziah Ambar Parawansa ${ }^{1}$, Rizki Dwi Siswanto ${ }^{2}$ \\ ${ }^{1,2}$ Pendidikan Matematika, Fakultas Keguruan dan Ilmu Pendidikan, Universitas Muhammadiyah Prof. DR. HAMKA \\ Jl. Tanah Merdeka No.20 Jakarta Timur, Indonesia \\ fauzihambar@gmail.com
}

\begin{abstract}
This study aims to analyze the epistemological barriers of students in solving social arithmetic problems to learn styles. This research method is included in qualitative descriptive research. The technique used purposive sampling with the subject of 6 students comprising 1 male student with visual learning style, 1 female student with visual learning style, 1 male student with auditory learning style, 1 female student with auditory learning style, 1 student male student with kinesthetic learning style, and 1 female student with kinesthetic learning style. The instruments in this study were a learning style questionnaire and a social arithmetic test. The data analysis in this research is data categorization and reduction, data presentation, and conclusion drawing. The triangulation technique is carried out by conducting the validity of the data, namely comparing the results of the subject's social arithmetic test with the interview. The results of this study are that male and female auditory learning style subjects experience fewer epistemological obstacle than male and female gender visual learning style subjects and male and female kinesthetic learning style subjects. Epistemological obstacle experienced by female gender subjects were less than male gender subjects.
\end{abstract}

Keywords: Epistemological Obstacle, Social Arithmetic, Learning Style, Gender

\begin{abstract}
Abstrak
Penelitian ini bertujuan untuk menganalisis hambatan epistemologi peserta didik dalam menyelesaikan soal aritmatika sosial yang ditinjau dari gaya belajar. Metode penelitian ini termasuk dalam penelitian deskriptif kualitatif. Teknik yang digunakan purposive sampling dengan subjek 6 peserta didik terdiri dari 1 peserta didik laki-laki bergaya belajar visual, 1 peserta didik perempuan bergaya belajar visual, 1 peserta didiki laki-laki bergaya belajar auditorial, 1 peserta didik perempuan bergaya belajar auditorial, 1 peserta didik laki-laki bergaya belajar kinestetik, dan 1 peserta didik perempuan bergaya belajar kinestetik. Instrumen dalam penelitian ini berupa angket gaya belajar dan tes aritmatika sosial. Analisis data pada penelitian ini yaitu kategorisasi dan reduksi data, penyajian data, dan pengambilan kesimpulan. Teknik triangulasi dilakukan dengan melakukan keabsahan data yaitu membandingkan hasil tes aritmatika sosial subjek dengan wawancaranya. Hasil dari penelitian ini adalah subjek bergaya belajar auditorial bergender laki-laki maupun perempuan lebih sedikit mengalami hambatan epistemologi daripada subjek bergaya belajar visual bergender laki-laki maupun perempuan dan subjek bergaya belajar kinestetik bergender laki-laki maupun perempuan. Hambatan epistemologi yang dialami subjek bergender perempuan lebih sedikit daripada subjek bergender laki-laki.
\end{abstract}

Kata kunci: Hambatan Epistemologi, Aritmatika Sosial, Gaya Belajar, Gender

Copyright (c) 2021 Fauziah Ambar Parawansa, Rizki Dwi Siswanto

$\square$ Corresponding author: Rizki Dwi Siswanto

Email Address: rizkidwisiswanto@uhamka.ac.id (Jl. Tanah Merdeka No.20 Jakarta Timur, Indonesia)

Received 30 June 2021, Accepted 06 July 2021, Published 08 August 2021

\section{PENDAHULUAN}

Pembelajaran pada Pendidikan Dasar dan Pendidikan Menengah menyatakan bahwa proses pembelajaran dilaksanakan secara interaktif, menantang, inspiratif, menyenangkan, memotivasi peserta didik untuk berpatisipasi aktif, memberi ruang yang cukup bagi prakarsa, kemandirian, kreativitas, minat, kemampuan, dan perkembangan fisik dan psikologis peserta didik (Peraturan Menteri Pendidikan Dan Kebudayaan Republik Indonesia Nomor 103 Tahun 2014 Tentang Pembelajaran Pada Pendidikan Dasar Dan Pendidikan Menengah, 2014). Setiap peserta didik berhak mendapatkan pengajaran yang memuaskan (Basiran, 2012). Namun fakta dilapangan menunjukkan bahwa peserta didik memiliki kemampuan dan 
kebutuhan yang berbeda-beda. Perbedaan dalam individu ini yang menyebabkan hadirnya perbedaan tingkah laku belajar peserta didik sehingga peserta didik tidak dapat belajar dengan maksimal (Basiran, 2012).

Akibatnya pembelajaran pada peserta didik tidak memenuhi kebutuhan peserta didik sehingga peserta didik akan mengalami hambatan ketika mengikuti kegiatan pembelajaran (Maghfirah et al., 2017). Brousseau mengungkapkan terdapat tiga learning obstacle yaitu hambatan ontogeni, hambatan didaktical, dan hambatan epistemologi (Rohimah, 2017). Hambatan ontogeni yaitu kesenjangan antara pembelajaran yang diberikan ke peserta didik dengan proses berpikir peserta didik, sehingga adanya kesulitan dalam proses pembelajaran (Insani \& Kadarisma, 2020). Hambatan didaktical yaitu hambatan yang dialami oleh peserta didik akibat pengajaran yang dilakukan guru ke peserta didik (Siswanto, 2020). Hambatan epistemologi yaitu adanya kesulitan dalam proses pembelajaran akibat keterbatasan pengetahuan peserta didik pada konteks tertentu, apabila mengahadapi konteks berbeda maka peserta didik akan mengalami hambatan seolah pengetahuan sebelumnya tidak berfungsi (Rohimah, 2017; Siswanto, 2020).

Pada penelitian ini learning obstacle yang akan dianalalisis oleh peneliti hanya hambatan epistemologi karena hambatan ini yang sering terjadi pada peserta didik ketika menyelesaikan soal cerita, seperti pernyataan Brousseau (Siswanto, 2020) hambatan epistemologi disebabkan adanya keterbatasan pengetahuan seseorang dalam konteks tertentu. Soal cerita adalah soal yang dibuat dalam bentuk cerita dan berkaitan dengan kehidupan sehari-hari (Rahmawati \& Permata, 2018). Menurut Susanti dalam menyelesaikan soal cerita peserta didik merasa cenderung lebih sulit untuk memecahkannya dibandingkan soal yang hanya berisi bilangan saja (Rahmawati \& Permata, 2018). Salah satu materi dengan bentuk soal bertipe cerita adalah aritmatika sosial. Aritmatika sosial merupakan materi matematika yang berkaitan langsung dengan kehidupan sehari-hari seperti untung dan rugi, harga jual dan harga beli, diskon, netto, bruto, tara, serta bunga tunggal (Dila \& Zanthy, 2020; Inayah et al., 2018).

Berdasarkan hasil wawancara peneliti dengan salah satu guru matematika pada SMPN 170 Jakarta diperoleh informasi bahwa dalam pembelajaran matematika seringkali guru dihadapkan dengan banyaknya peserta didik yang melakukan kesalahan dalam menyelesaikan soal aritmatika sosial. Kesalahan tersebut berupa kesalahan dalam menerjemahkan soal cerita ke dalam kalimat matematika, kesalahan konsep, serta kesalahan dalam berhitung. Dari hasil wawancara tersebut terlihat bahwa banyak peserta didik yang mengalami hambatan sesuai dengan tipe hambatan epistemologi, menurut Kastalon hambatan epistemologi peserta didik meliputi hambatan konseptual, hambatan prosedural, dan hambatan teknik operasional (Elfiah et al., 2020).

Menurut Syah hambatan epistemologi yang dialami oleh peserta didik dapat disebabkan oleh dua faktor, yaitu faktor eksternal (lingkungan keluarga, lingkungan masyarakat, serta lingkungan sekolah), dan faktor internal (minat, motivasi, sikap, kesehatan mental, gaya belajar) (Indrawati, 2019). Dalam mengerjakan soal matematika adanya perbedaan gaya belajar mempengaruhi kesulitan yang dirasakan oleh peserta didik karena setiap gaya belajar memiliki titik fokus yang berbeda-beda (Ernawati et al., 2019). Menurut Soleha et al. (2019) gaya belajar merupakan cara konsisten yang dilakukan oleh peserta didik 
dalam menangkap stimulus atau informasi, cara mengingat, berpikir, dan memecahkan soal. DePorter \& Hernacki (1999) mengemukakan gaya belajar seseorang adalah kombinasi dari bagaimana ia menyerap, kemudian mengatur serta mengolah informasi. DePorter dan Hernacki menyatakan bahwa terdapat tiga macam gaya belajar yang biasa disebut VAK, yaitu visual (belajar dengan melihat), auditorial (belajar dengan mendengar), dan kinestetik (belajar dengan bergerak dan mencoba) (Sundayana, 2018).

Gaya belajar yang dimiliki setiap peserta didik berbeda-beda, apalagi peserta didik terdiri dari bermacam-macam karakteristik serta gender. Nugraha \& Pujiastuti menyatakan perbedaan jenis kelamin peserta didik (gender) dapat mengakibatkan perbedaan psikologi belajar peserta didik (Purwaningsih \& Ardani, 2020). Perbedaan gender bukan hanya berakibat pada kemampuan dalam matematika tetapi memperoleh pengetahuan matematika itu sendiri (Aliyah et al., 2019). Menurut Nur \& Pablo gender juga bisa menjadi faktor yang membedakan peserta didik dalam mengolah informasi dan belajar (Maryanto \& Siswanto, 2021). Gender yang dimaksud dalam penelitian ini dibedakan menjadi laki-laki dan perempuan.

Berdasarkan penjelasan di atas mengenai hambatan epistemologi, gaya belajar dan gender laki-laki maupun perempuan, maka penelitian ini bertujuan menganalisis hambatan epistemologi peserta didik dalam menyelesaikan soal aritmatika sosial berdasarkan gaya belajar dan perbedaan gender.

\section{METODE}

Penelitian ini menggunakan metode deskriptif kualitatif dengan tujuan untuk menganalisis hambatan epistemologi peserta didik dalam menyelesaikan soal aritmatika sosial ditinjau dari gaya belajar. Penelitian ini dilakukan di SMP Negeri 151 Jakarta via Zoom dan Google Form karena pada saat penelitian dilakukan dalam kondisi pandemi Covid-19. Subjek penelitian 6 peserta didik, terdiri dari 1 peserta didik laki-laki bergaya belajar visual, 1 peserta didik perempuan bergaya belajar visual, 1 peserta didik laki-laki bergaya belajar audio, 1 peserta didik perempuan bergaya belajar audio, 1 peserta didik laki-laki bergaya belajar kinestetik, 1 peserta didik perempuan bergaya belajar kinestetik. Penentuan dan pengkategorian subjek penelitian bergaya belajar visual, audio dan kinestetik menggunakan modifikasi instrumen angket gaya belajar buatan DePorter \& Hernacki (1999) yang dikembangkan oleh Mulyati (2015) dimana peserta didik mengerjakan angket gaya belajar tersebut via Google Form yang sudah dibuat oleh peneliti dengan ketentuan skor tertinggi.

Tes aritmatika sosial yang diberikan yaitu tes uraian berbetuk soal cerita sebanyak 3 soal dengan tujuan untuk pengambilan data terkait epistemological obstacle yang dialami subjek penelitian. Menurut Kastalon (Elfiah et al., 2020), epistemological obstacle dapat dikategorikan menjadi hambatan konseptual, hambatan prosedural, dan hambatan teknik operasional. Wawancara dilakukan semi terstruktur dengan menggunakan panduan ketika proses wawancara untuk menggali hambatan epistemologi yang dialami subjek, selain itu peneliti juga mengembangkan pertanyaannya pada saat wawancara dengan alur pembahasan yang masih tetap. Peneliti juga menggunakan dokumentasi sebagai alat bantu untuk mengumpulkan data berupa foto-foto, hasil jawaban peserta didik, dan video record wawancara via Zoom. 
Analisis data menggunakan model Miles dan Huberman (Sugiyono, 2018), yaitu reduksi data dan kategorisasi, penyajian data, penarikan kesimpulan. Uji keabsahan dengan teknik triangulasi dengan membandingkan hasil tes soal cerita aritmatika sosial subjek dengan wawancaranya.

\section{HASIL DAN DISKUSI}

Berdasakan angket gaya belajar yang sudah dilakukan oleh 27 peserta didik didapatkan hasil dari angket gaya belajar seperti yang tertera dalam tabel 1 .

Tabel 1. Hasil Angket Gaya Belajar

\begin{tabular}{|c|c|c|}
\hline Visual & Auditorial & Kinestetik \\
\hline 12 & 8 & 7 \\
\hline
\end{tabular}

Dari hasil angket gaya belajar pada tabel 1, didapat bahwa dari 27 peserta didik yang mengisi angket gaya belajar terdapat 12 peserta didik memiliki gaya belajar visual, 8 peserta didik memiliki gaya belajar auditorial, dan 7 peserta didik memiliki gaya belajar kinestetik. Kemudian peneliti memilih 6 peserta didik sebagai subjek penelitian dalam Tabel 2 yang terdiri dari 1 peserta didik laki-laki bergaya belajar visual (VL), 1 peserta didik perempuan bergaya belajar visual (VP), 1 peserta didik laki-laki bergaya belajar auditorial (AL), 1 peserta didik perempuan bergaya belajar auditorial (AP), 1 peserta didik laki-laki bergaya belajar kinestetik (KL), dan 1 peserta didik perempuan bergaya belajar kinestetik (KP).

Tabel 2. Kategori Subjek Penelitian

\begin{tabular}{|c|c|c|c|c|c|}
\hline \multirow{2}{*}{ No } & \multirow{2}{*}{ Nama } & \multirow{2}{*}{ Gender } & \multicolumn{3}{|c|}{ Gaya Belajar } \\
\hline & & Visual & Auditorial & Kinestetik \\
\hline 1 & RHP & Laki-laki & $\checkmark$ & & \\
\hline 2 & FAP & Perempuan & $\checkmark$ & & \\
\hline 3 & YA & Laki-laki & & $\checkmark$ & \\
\hline 4 & SS & Perempuan & & $\checkmark$ & \\
\hline 5 & MAN & Laki-laki & & & $\checkmark$ \\
\hline 6 & NSR & Perempuan & & & $\checkmark$ \\
\hline
\end{tabular}

\section{Hambatan Konseptual}

Pertanyaan mengenai kesalahan konsep terletak pada nomor 1, pertanyaan yang diajukan kepada peserta didik sebagai berikut "Pada awal bulan februari 2019, Pak Tama meminjam uang di Bank sebesar Rp.25.000.000 dengan bunga 2\% per tahun. Pak Tama mengembalikan pinjaman tersebut pada bulan Juli 2020. Hitunglah berapa jumlah uang yang dikembalikan oleh Pak Tama!”. Dari pertanyaan tersebut disajikan jawaban pertanyaan nomor 1 dari VL pada Gambar 1 dan kutipan wawancara. 


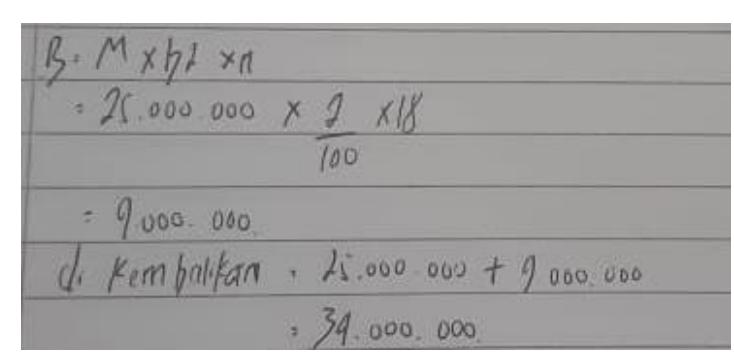

(a)

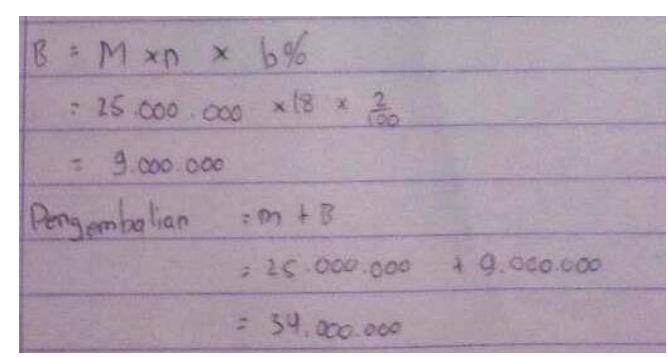

(b)

Gambar 1. (a) Jawaban VL pada Pertanyaan Nomor 1 dan

(b) Jawaban VP pada Pertanyaan Nomor 1

Berdasakan jawaban subjek VL pada Gambar 1, menunjukkan bahwa VL mengalami kesalahan konsep. Subjek VL belum mampu menuliskan rumus secara tepat, seharusnya $B=M \times \frac{n}{12} \times b \%$ karena bunga yang dibebankan bank pada soal $2 \%$ per tahun bukan per bulan tetapi hanya menuliskan $B=$ $M \times b \% \times n$ saja. Untuk mengetahui penyebab kesalahan tersebut, peneliti melakukan wawancara. Berikut kutipan wawancara terhadap VL, dan VP.

$\begin{array}{ll}P & : \text { coba lihat jawaban nomor } 1 \\ V L, V P & : \text { (lihat jawaban nomor } 1) \\ P & : \text { menurut kamu udah bener atau kurang tepat? } \\ V L & : \text { harusnya rumusnya ada per } 12 \text { ya ka? } \\ P & : \text { iya bener, kenapa bisa per } 12 ? \\ V L & : \text { karna bunganya per tahun ya } \\ V P & : \text { lama menabungnya juga } 18 \text { bulan kan } \\ P & : \text { nah bener, jadi mangkanya rumusnya harus ditambah n per } 12 \\ V L & : \text { oh gitu ya ka } \\ P & : \text { Terus kemaren gak paham atau gimana? } \\ V P & : \text { kebiasaan disekolah ka selalu make rumus itu } \\ V L & : \text { sama ka }\end{array}$

Berdasarkan kutipan wawancara pertanyaan nomor 1 tersebut terlihat bahwa subjek VL dan VP dapat membenarkan kesalahannya tetapi karena kurangnya ketelitian dalam membaca soal dan kurangnya referensi soal yang diberikan sebelumnya sehingga terjadi kesalahan konsep. Selanjutnya, disajikan jawaban pertanyaan nomor 1 dari AL pada Gambar 2 dan kutipan wawancara.

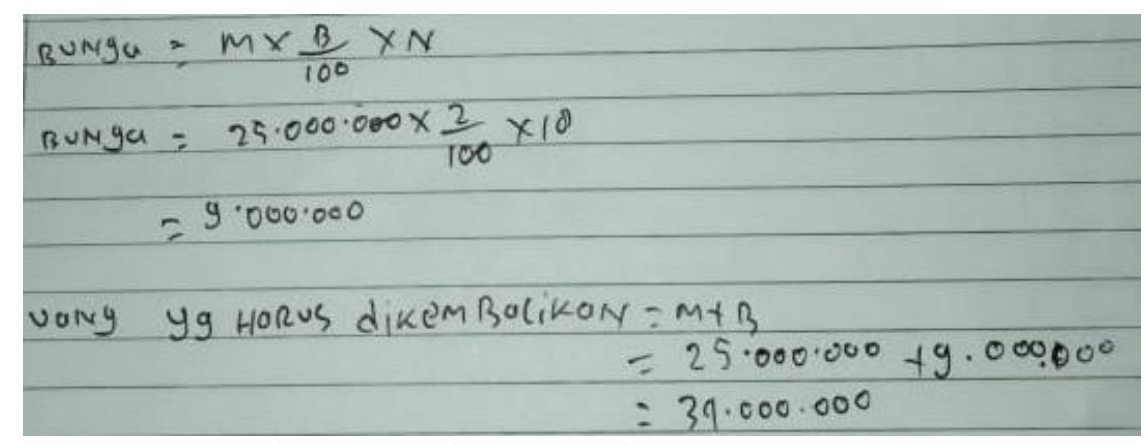

Gambar 2. Jawaban AL pada Pertanyaan Nomor 1 
Hambatan Epistemologi Peserta Didik dalam Menyelesaikan Aritmatika Sosial Berdasarkan Gaya Belajar dan Perbedaan Gender, Fauziah Ambar Parawansa, Rizki Dwi Siswanto

Berdasarkan jawaban AL pada Gambar 2, menunjukkan bahwa AL mengalami kesalahan serupa dengan VL dan VP dimana belum mampu menuliskan rumus dengan tepat. AL hanya menuliskan $B=$ $M \times \frac{b}{100} \times n$ saja. Untuk mengetahui penyebab terjadinya hambatan tersebut peneliti melakukan wawancara. Berikut kutipan wawancara dengan AL.

$P \quad$ : coba kamu lihat jawaban nomor 1

AL : (melihat jawaban nomor 1)

$P \quad$ : Kenapa kamu nulis rumusnya begini

AL : : kan make rumus bunga tunggal ka

$P \quad$ : ya pake rumus bunga tunggal, tapi kalo soalnya kaya gini rumusnya bener?

AL $\quad$ : saya cuma tau rumusnya gitu aja ka, karena di sekolah kan rumusnya itu aja

$P \quad$ : coba lihat bunganya per bulan apa per tahun?

AL : per tahun ka

$P \quad$ : nah karena bunganya per tahun lama menabungnya 18 bulan, harusnya rumusnya ditambah jadi $n$ per 12

AL : ohh gitu ya ka

Berdasarkan kutipan wawancara pertanyaan nomor 1 tersebut terlihat bahwa subjek AL dapat melakukan kesalahan konsep karena kurangnya pemahaman pada materi dan kurangnya referensi soal yang diberikan sebelumnya. Selanjutnya, disajikan jawaban pertanyaan nomor 1 dari AP pada Gambar 3 dan kutipan wawancara.

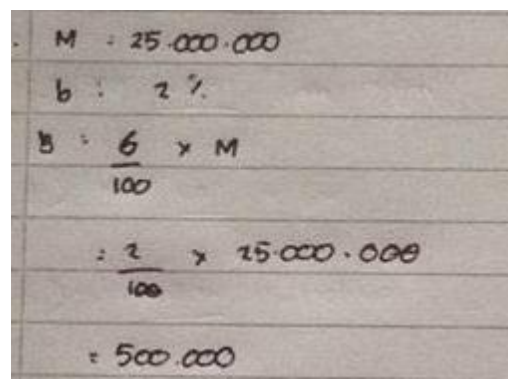

Gambar 3. Jawaban AP pada Pertanyaan Nomor 1

Berdasarkan jawaban subjek AP pada Gambar 3, menunjukkan bahwa AP melakukan kesalahan dalam menuliskan rumus yang seharusnya $B=M \times \frac{n}{12} \times b \%$ tetapi hanya menuliskan $B=\frac{b}{100} \times M$ saja. Untuk mengetahui penyebab kesalahan tersebut, peneliti melakukan wawancara. Berikut kutipan wawancara terhadap AP.

$P \quad$ : coba lihat jawaban nomor 3

AP : (melihat jawaban nomor 3 )

$P \quad$ : menurut kamu apa ada yang salah?

AP : : hmmm...saya kurang ngerti si ka sebenernya

$P \quad$ : terus kenapa kamu dapet jawaban kaya gitu?

AP : : saya cuma kali kaliin aja ka yang ada di soal 
$P \quad:$ kaya gimana?

AP $\quad$ : kan bunganya $2 \%$ modalnya 25.000 .0000 saya kaliiin aja ka

P $\quad$ : terus yang bulan februari 2019 sampe juli 2020, ga diapa apain?

$A P \quad$ : enggak ka, saya kurang ngerti soalnya

$P \quad:$ kalo rumus bunga tunggal tapi tau?

AP : lupa ka

Berdasarkan kutipan wawancara pertanyaan nomor 1 tersebut terlihat bahwa AP kurang memahami soal dan materi aritmatika sosial. Selanjutnya, disajikan jawaban pertanyaan nomor 1 dari KL pada Gambar 4 dan kutipan wawancara.

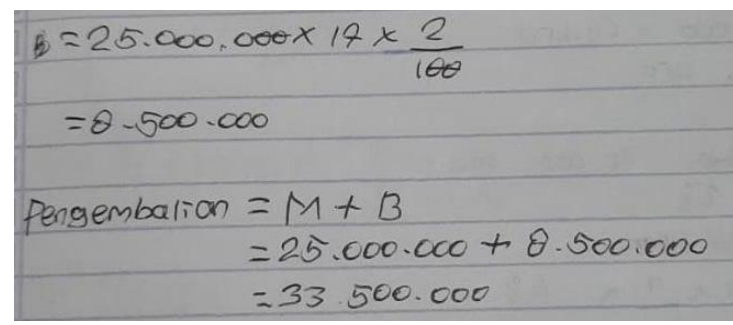

Gambar 4. Jawaban KL pada Pertanyaan Nomor 1

Berdasarkan jawaban subjek KL pada Gambar 4, menujukkan bahwa KL mengalami kesalahan sama seperti VL dan VP dimana tidak menggunakan rumus secara tepat. Seharusnya $B=M \times \frac{n}{12} \times b \%$ dan KL juga tidak menuliskan rumusnya terlebih dahulu. Untuk mengetahui penyebab kesalahan tersebut, peneliti melakukan wawancara. Berikut kutipan wawancara terhadap KL.

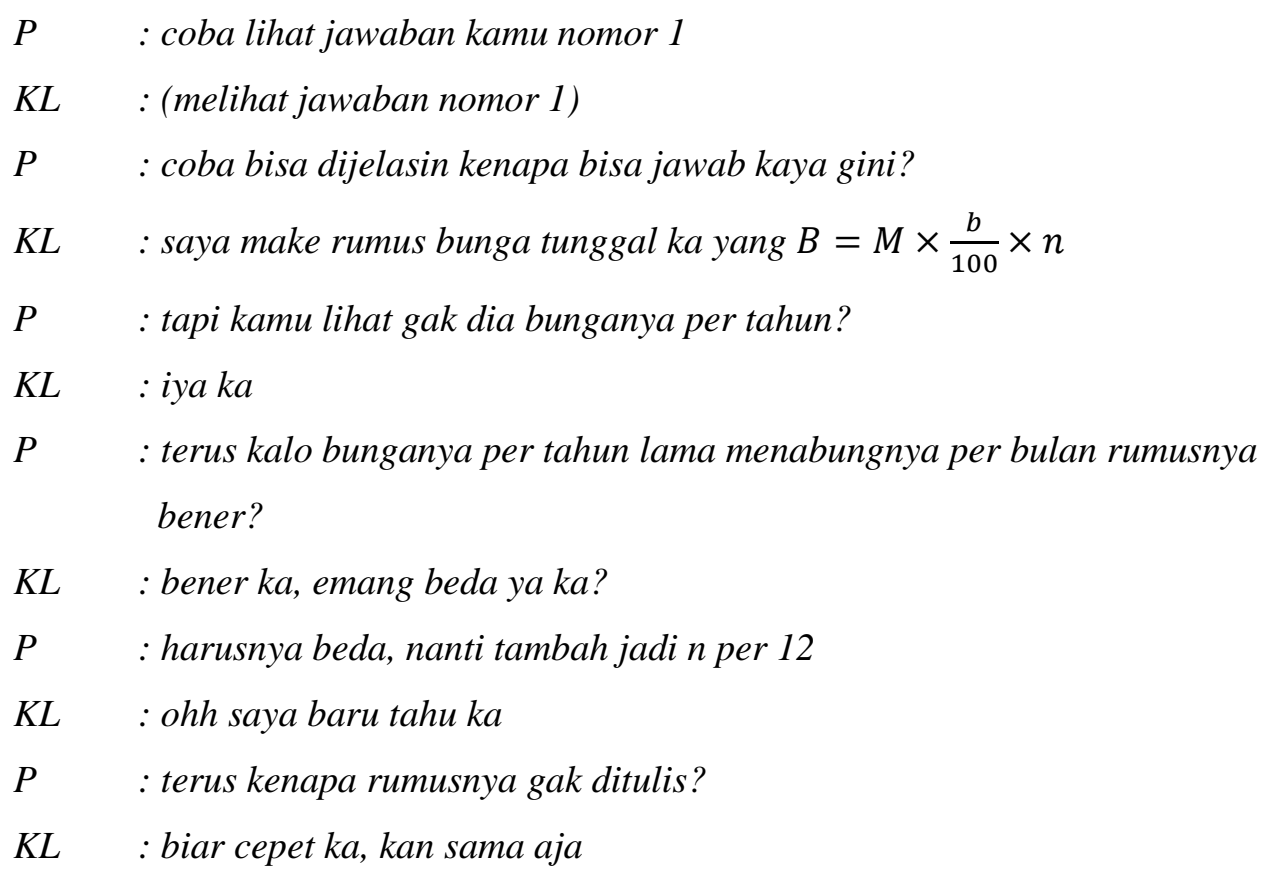

Berdasarkan kutipan wawancara pertanyaan nomor 1 tersebut terlihat bahwa KL kurang memahami konsep aritmatika sosial dan melakukan perhitungan tanpa menuliskan rumus yang digunakan terlebih dahulu untuk mempersingkat waktu pengerjaan. Selanjutnya, disajikan jawaban petanyaan nomor 1 dari KP pada Gambar 5. 


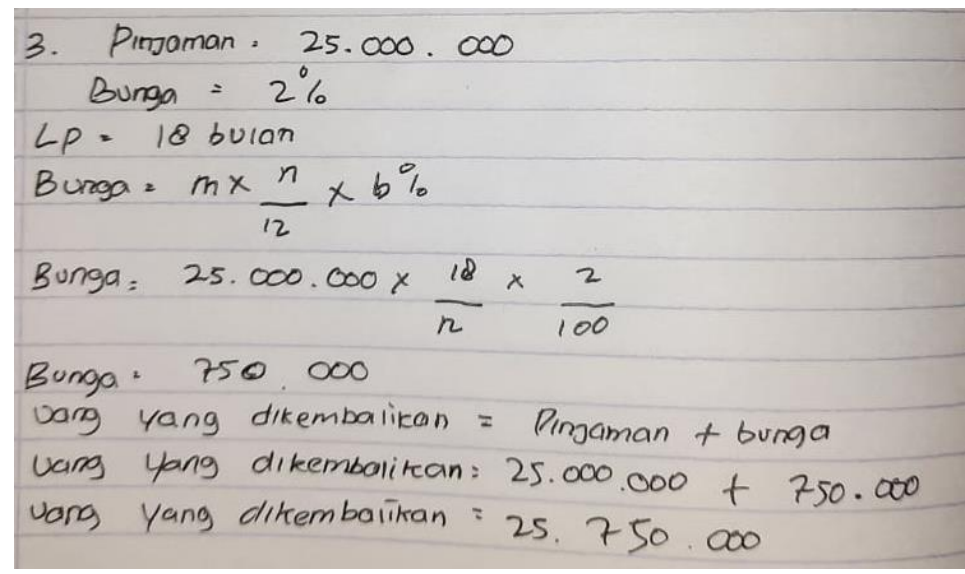

Gambar 5. Jawaban KP pada Pertanyaan Nomor 1

Berdasarkan jawaban subjek KP pada Gambar 5, menunjukkan bahwa KP tidak melakukan kesalahan konsep. Terlihat juga bahwa KP sudah mampu menyelesaikan permasalahan yang diberikan secara tepat.

\section{Hambatan Prosedural}

Hambatan prosedural pada penelitian ini terletak pada pertanyaan nomor 2, pertanyaan yang diajukan kepada peserta didik sebagai berikut "Seorang pedagang membeli 1 karung beras yang mempunyai berat $8 \mathrm{~kg}$ dengan harga 90.000. Setelah ditimbang ternyata berat dari karung itu sendiri adalah 0,25 kg. Jika pedagang tersebut menjualnya dengan harga 9.000/kg. Tentukan kondisi yang dialami pedagang tersebut untung ataukah rugi! Serta hitunglah besar keuntungan dan kerugiannya!”. Dari pertanyaan tersebut disajikan hasil jawaban VL dan VP pada Gambar 6.

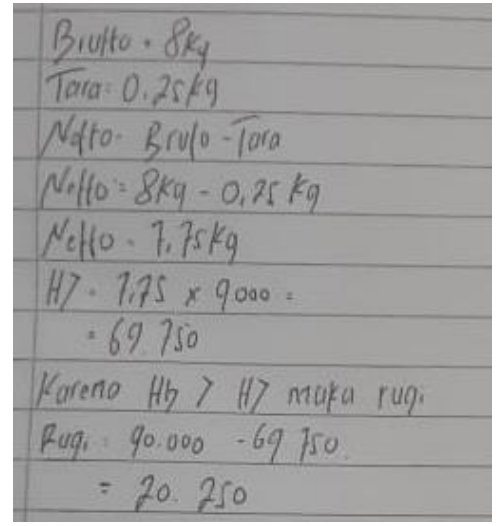

(a)

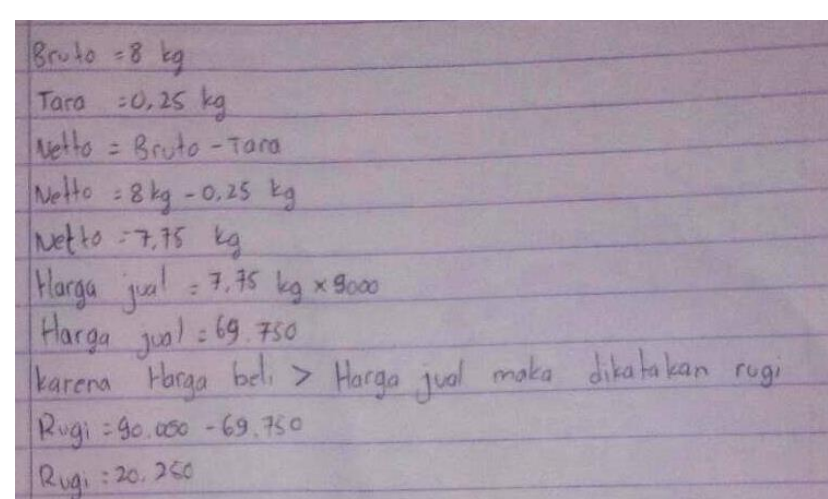

(b)

Gambar 6. (a) Jawaban VL pada Pertanyaan Nomor 2 dan

(b) Jawaban VP pada Pertanyaan Nomor 2

Berdasarkan jawaban VL dan VP pada Gambar 6, menunjukkan bahwa subjek VLdan VP tidak melakukan kesalahan prosedural. Dari jawaban tersebut juga terlihat subjek VL dan VP sudah mampu menyelesaikan permasalahan yang diberikan secara tepat. Selanjutnya, disajikan jawaban pertanyaan nomor 2 dari AL dan AP pada Gambar 7 dan kutipan wawancara terkait pertanyaan yang diberikan. 


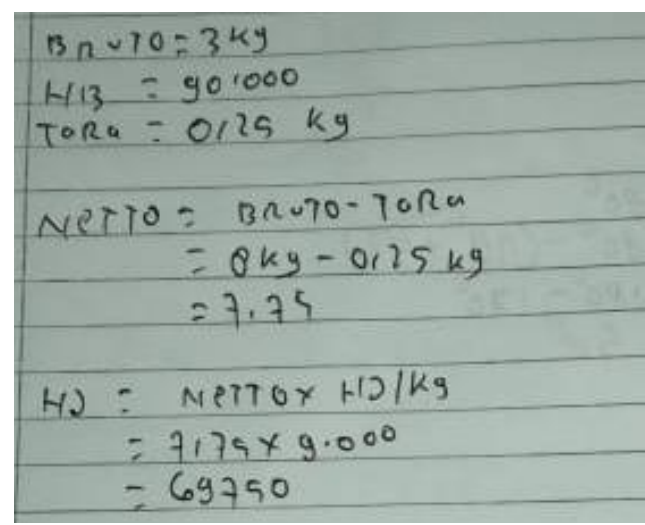

Gambar 7. Jawaban AL pada Pertanyaan Nomor 2

Berdasarkan jawaban subjek AL pada Gambar 7, menunjukkan bahwa AL mengalami kesalahan prosedur. Subjek AL melakukan kesalahan dalam menyelesaikan soal, subjek AL hanya mengerjakan sampai mencari harga jual saja. Hal itu tidak sesuai dengan prosedur yang diharapkan oleh peneliti. Karena seharusnya ada langkah terakhir yaitu untuk mencari besarnya kerugian. Untuk mengetahui penyebab terjadinya hambatan tersebut peneliti melakukan wawancara. Berikut kutipan wawancara dengan AL.

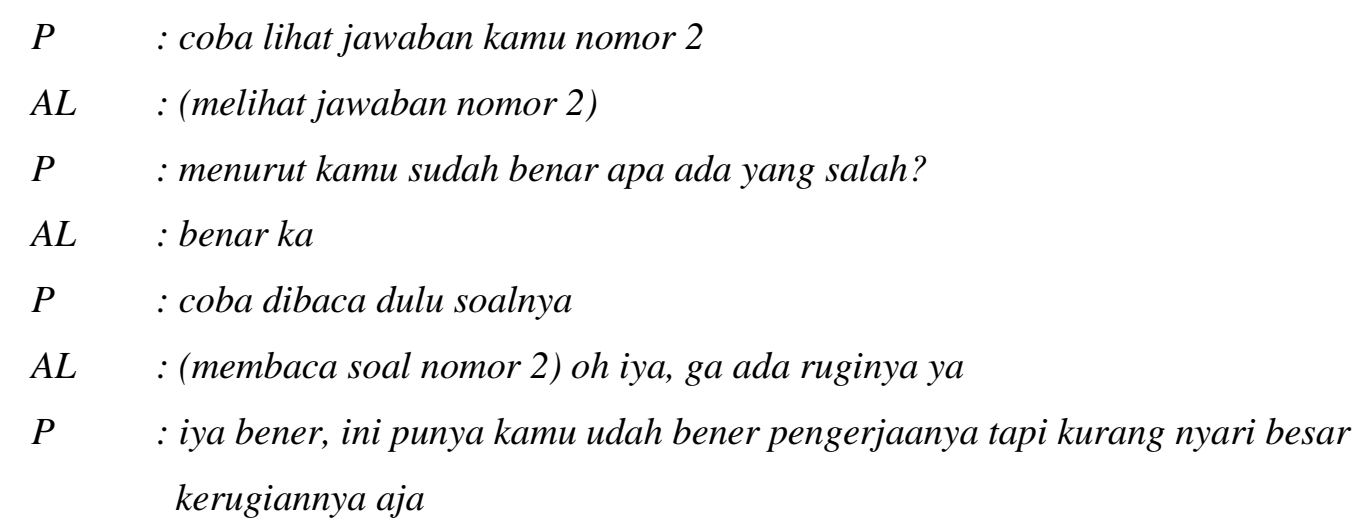

AL : : saya lupa kayanya waktu ngerjain, buru-buru juga ka kemaren

Berdasarkan kutipan wawancara diatas terlihat bahwa hambatan prosedural terjadi karena kurangnya ketelitian dan terburu-buru dalam mengerjakan soal aritmatika sosial. Selanjutnya, disajikan jawaban pertanyaan nomor 2 dari AP pada Gambar 8 dan kutipan wawancara.

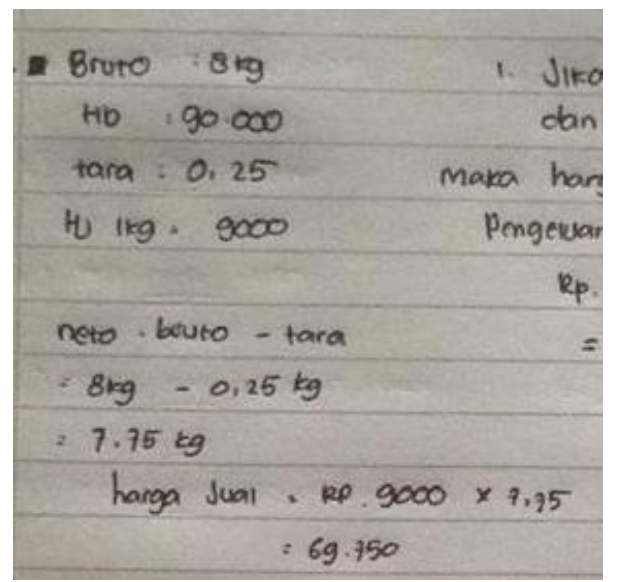

Gambar 8. Jawaban AP pada Pertanyaan Nomor 2 
Hambatan Epistemologi Peserta Didik dalam Menyelesaikan Aritmatika Sosial Berdasarkan Gaya Belajar dan Perbedaan Gender, Fauziah Ambar Parawansa, Rizki Dwi Siswanto

Berdasarkan jawaban subjek AP pada Gambar 8, menunjukkan bahwa AP juga mengalami hal yang serupa dengan AL yang tidak selesai dalam menyelesaikan langkah pengerjaan yang diharapkan oleh peneliti. Untuk mengetahui penyebab terjadinya hambatan tersebut peneliti melakukan wawancara. Berikut kutipan wawancara dengan AL.

$P \quad$ : coba lihat jawaban kamu nomor 2

AP $\quad:$ (melihat jawaban nomor 2)

$P \quad$ : menurut kamu sudah benar apa kurang tepat?

AP $\quad:$ hmm ... oiya ini disuruh cari besar untung atau ruginya ya

$P \quad$ : iya terus, kamu cari ga tapi?

AP : enggak ka, lupa

$P \quad$ : tapi kamu ngerti? gimana cara nyarinya?

AP $\quad$ : ngerti ka, itu berartikan nyari rugi tinggal harga beli dikurang harga jual

Berdasarkan kutipan wawancara tersebut terlihat bahwa AP mengerti bagaimana untuk melanjutkan jawaban tersebut tetapi karena kurangnya ketelitian dalam mengerjakan soal aritmatika sosial membuat AP mengalami kesalahan prosedur. Selanjutnya, disajikan jawaban pertanyaan nomor 2 dari KL pada Gambar 9 dan kutipan wawancara.

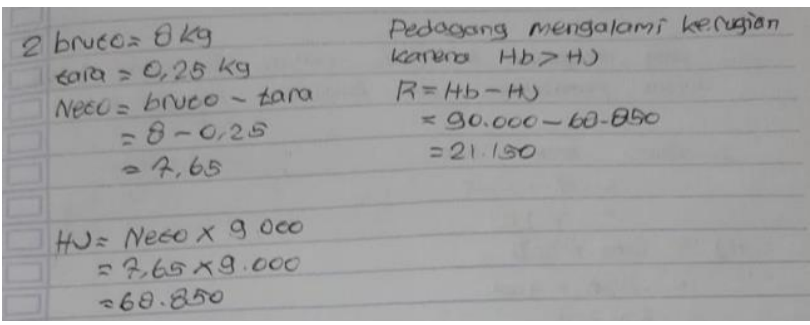

Gambar 9. Jawaban KL pada Pertanyaan Nomor 2

Berdasarkan jawaban subjek KL pada Gambar 9, menunjukkan bahwa KL melakukan kesalahan dalam menghitung $8-0,25=7,65$ padahal sebenarnya adalah 7,75. Untuk mengetahui penyebab terjadinya hambatan tersebut peneliti melakukan wawancara. Berikut kutipan wawancara dengan KL.

$P \quad$ : coba lihat jawaban nomor 2

KL $\quad$ :(melihat jawaban nomor 2$)$

$P \quad:$ menurut kamu sudah benar apa kurang tepat?

KL : bener ka

$P \quad$ : coba sekarang kamu lihat yang 8-0,25 itu bener 7,65?

KL : oiya salah $k a$

$P \quad$ : harusnya berapa?

KL $\quad: 7,75$

$P \quad$ : ayo kenapa bisa salah kemaren?

KL : enggak teliti berarti ka, tapi kemaren si ngerasanya bener 
Berdasarkan kutipan wawancara tersebut terlihat bahwa KL tidak mengalami hambatan prosedural tetapi KL mengalami hambatan teknik operasional saat berhitung karena kurangnya ketelitian. Selanjutnya, disajikan jawaban pertanyaan nomor 2 dari KP pada Gambar 10 dan kutipan wawancara.

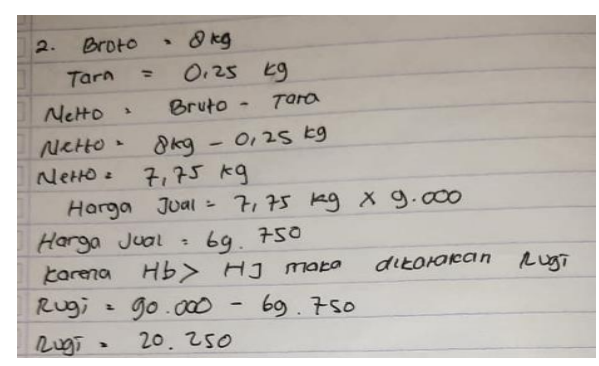

Gambar 10. Jawaban KP pada Pertanyaan Nomor 2

Berdasarkan jawaban subjek KP pada Gambar 10, menunjukkan bahwa subjek KP tidak melakukan kesalahan prosedur. Dari jawaban tersebut terlihat KP sudah mampu menyelesaikan permasalahan yang diberikan secara tepat.

\section{Hambatan Teknik Operasional}

Hambatan teknik operasional dalam penelitian ini terdapat pada pernyataan nomor 3, pernyataaan yang diajukan kepada peserta didik sebagai berikut "Berat brutto dari sekarung kacang kedelai adalah 110 kg. Jika taranya 3,5\% maka tentukan berat netto kacang kedelai!". Dari pertanyaan tersebut disajikan jawaban subjek VL pada Gambar 11.

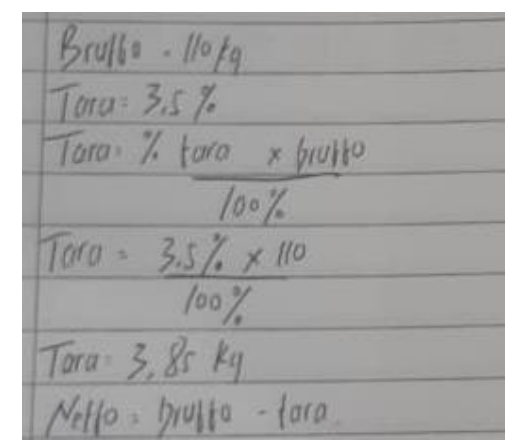

Gambar 11. Jawaban VL pada Pertanyaan Nomor 3

Berdasarkan jawaban subjek VL pada Gambar 11, menunjukkan bahwa VL melakukan kesalahan dalam menyelesaikan soal, VL hanya menyelesaikan soal sampai menghitung besar tara saja. Hal itu tidak sesuai dengan prosedur yang diharapkan oleh peneliti. Karena seharusnya ada langkah terakhir yaitu untuk mencari besarnya netto. Untuk mengetahui penyebab terjadinya hambatan tersebut peneliti melakukan wawancara. Berikut kutipan wawancara dengan VL.
$P \quad$ : coba kamu lihat jawaban nomor 3
$V L \quad:($ melihat jawaban nomor 3)
$P \quad$ : kenapa ini gak dilanjutin
$V L \quad$ : oiya salah lupa ka lanjutinnya
$P \quad$ : buru-buru ya?
VL : iya ka hehe 
Hambatan Epistemologi Peserta Didik dalam Menyelesaikan Aritmatika Sosial Berdasarkan Gaya Belajar dan Perbedaan Gender, Fauziah Ambar Parawansa, Rizki Dwi Siswanto

$$
\begin{aligned}
& P \quad: \text { tapi ini kalo dilanjutin gimana? } \\
& V L \quad: 110-3,85 \text { itu } 106,15 \mathrm{ka}
\end{aligned}
$$

Berdasarkan wawancara terlihat bahwa VL tidak mengalami hambatan teknik melainkan hambatan prosedural karena tidak mengerjakan soal sampai langkah terakhir karena terburu-buru dalam mengerjakan soal. Selanjutnya, disajikan jawaban pertanyaan nomor 3 dari VP dan AL.

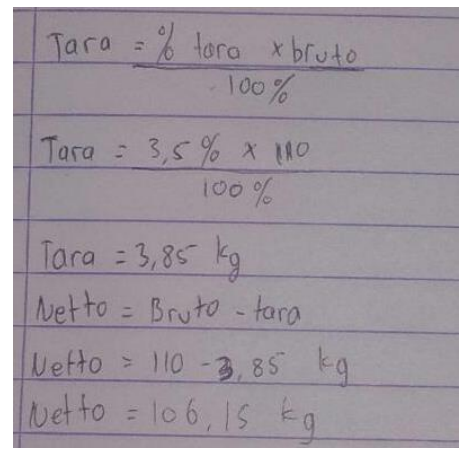

(a)

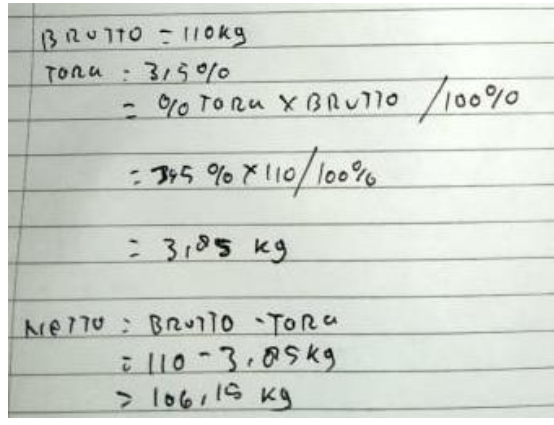

(b)

Gambar 12. (a) Jawaban VP pada Pertanyaan Nomor 3

dan (b) Jawaban AL pada Pertanyaan Nomor 3

Berdasarkan jawaban subjek VP dan AL pada Gambar 10, menunjukkan bahwa subjek VP dan AL tidak melakukan kesalahan teknik. Dari jawaban tersebut terlihat VP dan AL sudah mampu menyelesaikan permasalahan yang diberikan secara tepat. Selanjutnya, disajikan jawaban pertanyaan nomor 3 dari AP.

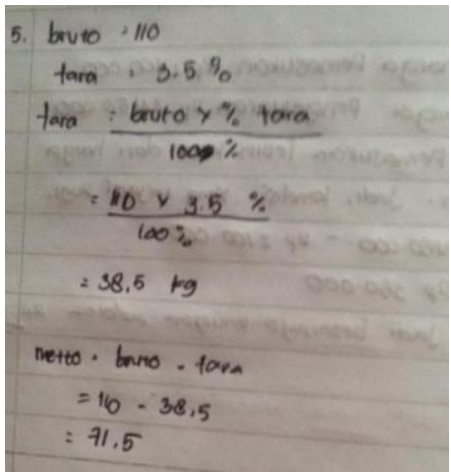

Gambar 13. Jawaban AP pada Nomor 3

Berdasarkan jawaban AP pada Gambar 13, subjek AP melakukan kesalahan dalam menghitung $\frac{110 \times 3.5 \%}{100 \%}=38,5$ padahal seharusnya adalah 3,85 . Untuk mengetahui penyebab terjadinya hambatan tersebut peneliti melakukan wawancara. Berikut kutipan wawancara dengan AP.

$P \quad$ : Coba kamu lihat jawaban nomor 3

AP : (lihat jawaban nomor 3)

$P \quad$ : nah coba lihat yang hasil tara, menurut kamu bener apa kurang tepat?

AP : (lihat jawaban nomor 3)

$P \quad$ : ayo gimana?

AP $\quad:$ 3,85 harusnya ka, salah ka

$P \quad$ : nah iya harusnya 3,85 ya bukan 38,5 


\section{AP : hehe iya ka, kemaren gak teliti ka}

$P \quad$ : siap ka

Berdasarkan hasil wawancara peneliti dengan subjek AP hal ini dapat terjadi karena ketidaktelitian AP dalam melakukan operasi hitung. Selanjutnya, disajikan jawaban pertanyaan nomor 3 dari KL.

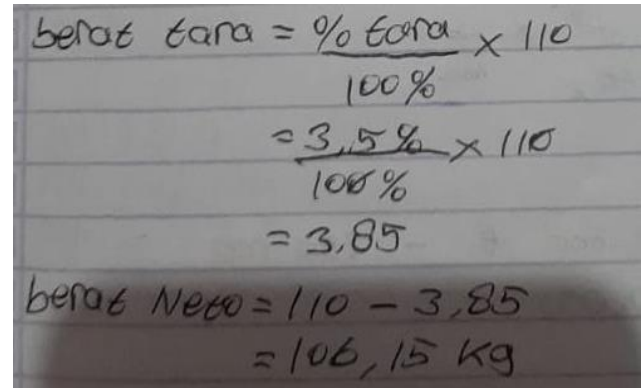

(a)

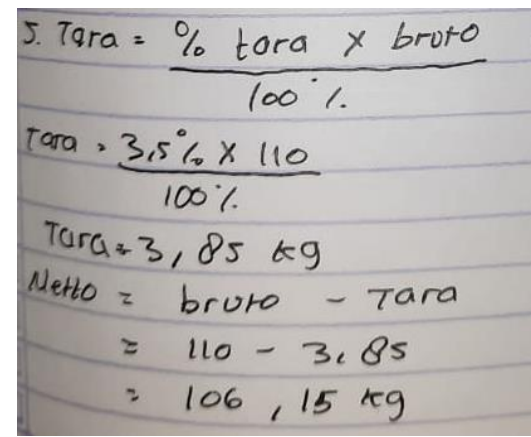

(b)

Gambar 14. (a) Jawaban KL pada Jawaban Nomor 3 dan (b) Jawaban KP pada Jawaban Nomor 3

Berdasarkan jawaban subjek KL dan KP pada Gambar 14, menunjukkan bahwa subjek KL dan KP tidak melakukan kesalahan teknik. Dari jawaban tersebut terlihat KL dan KP sudah mampu menyelesaikan permasalahan yang diberikan secara tepat.

Berdasarkan hasil deskripsi dari 6 subjek penelitian di atas, menunjukkan masih terjadinya hambatan epistemologi yang dilakukan oleh peserta didik. Hal ini memperlihatkan bahwa peserta didik merasa kesulitan dalam menyelesaikan soal aritmatika sosial. Hal ini sejalan dengan pernyataan Susanti dalam menyelesaikan soal cerita peserta didik merasa cenderung lebih sulit untuk memecahkannya dibandingkan soal yang hanya berisi bilangan saja (Rahmawati \& Permata, 2018).

Hambatan epistemologi yang dilakukan oleh peserta didik dapat berbeda-beda karena dipengaruhi oleh gaya belajar. Dalam mengerjakan soal matematika adanya perbedaan gaya belajar mempengaruhi kesulitan yang dirasakan oleh peserta didik karena setiap gaya belajar memiliki titik fokus yang berbedabeda (Ernawati et al., 2019). Subjek bergaya belajar visual mengalami hambatan prosedural dan teknik operasional, subjek bergaya belajar auditorial mengalami hambatan teknik saja, dan subjek bergaya belajar kinestetik mengalami hambatan konsep, prosedural dan teknik operasional. Hal ini sejalan Nuriza et al. (2019) dengan bahwa kesalahan yang cenderung dialami oleh peserta didik bergaya belajar visual adalah kesalahan teknis dan kurangnya pemahaman prosedur dengan benar, sedangkan kesalahan yang cenderung dilakukan peserta didik bergaya belajar auditorial adalah perhitungan matematika yang salah, dan kesalahan yang cenderung dilakukan peserta didik kinestetik adalah kurangnya pemahaman masalah, memahami prosedur yang benar, dan perhitungan matematika yang tidak tepat.

Selain dipengaruhi oleh gaya belajar, hambatan epistemologi yang dilakukan oleh peserta didik dapat berbeda-beda juga karena dipengaruhi oleh gender. Menurut Nur \& Pablo gender juga bisa menjadi faktor yang membedakan peserta didik dalam mengolah informasi dan belajar (Maryanto \& Siswanto, 2021). Subjek bergender laki-laki bergaya belajar visual, auditorial dan kinestetik lebih mampu menyelesaikan soal secara tepat dari subjek bergender perempuan bergaya belajar visual, auditorial dan 
kinestetik. Hal ini sependapat dengan Aminah \& Kurniawati (2018) bahwa kesalahan yang dilakukan peserta didik bergender perempuan lebih banyak dibanding peserta didik bergender laki-laki.

Secara umum hasil penelitian ini menyimpulkan hambatan epistemologis dalam pembelajaran matematika pada materi aritmatika sosial meliputi tiga tipe yaitu hambatan konseptual, hambatan prosedural, dan hambatan teknik operasional. Rangkuman hambatan epistemologi subjek penelitian seperti Tabel 3.

Tabel 3. Rangkuman Hambatan Epistemologi Subjek Penelitian

\begin{tabular}{|c|c|c|c|c|c|c|}
\hline \multirow{2}{*}{ Hambatan } & \multicolumn{7}{|c|}{ Subjek Penelitian } \\
\cline { 2 - 7 } & VL & VP & AL & AP & KL & KP \\
\hline Konseptual & $\boldsymbol{x}$ & $\boldsymbol{x}$ & $\boldsymbol{x}$ & $\boldsymbol{x}$ & $\boldsymbol{x}$ & $\checkmark$ \\
\hline Prosedural & $\checkmark$ & $\checkmark$ & $\boldsymbol{x}$ & $\boldsymbol{x}$ & $\checkmark$ & $\checkmark$ \\
\hline $\begin{array}{c}\text { Teknik } \\
\text { operasional }\end{array}$ & $\checkmark$ & $\checkmark$ & $\checkmark$ & $\boldsymbol{x}$ & $\checkmark$ & $\checkmark$ \\
\hline
\end{tabular}

\section{KESIMPULAN}

Secara keseluruhan hambatan epistemologi subjek bergaya belajar visual bergender laki-laki dan perempuan (VL dan VP) hanya melakukan hambatan prosedural dan teknik operasional. Subjek bergaya belajar auditorial bergender laki-laki (AL) hanya melakukan hambatan teknik operasional dan subjek bergaya belajar auditorial bergender perempuan (AP) tidak melakukan hambatan epistemologi. Subjek bergaya belajar kinestetik bergender laki-laki (KL) melakukan hambatan prosedural, dan teknik operasional sedangkan subjek bergaya belajar kinestetik bergender perempuan (KP) melakukan hambatan konsep, prosedural, dan teknik operasional.

\section{UCAPAN TERIMA KASIH}

Terimakasih kepada orang tua, Bapak Rizki Dwi Siswanto, M.Pd., dan SMP Negeri 151 Jakarta dan seluruh pihak yang terlibat atas dana, motivasi, dan tenaga dalam pelaksanaan kegiatan ini.

\section{REFERENSI}

Aliyah, I. M., Yuhana, Y., \& Anwar, C. A. H. F. S. (2019). Kemampuan Koneksi Matematis Siswa Ditinjau dari Kemampuan Awal dan Gender. Jurnal Didaktik Matematika, 6(2), 161-178. https://doi.org/10.24815/jdm.v6i2.14104

Aminah, A., \& Kurniawati, K. R. A. (2018). Analisis Kesulitan Siswa Dalam Menyelesaikan Soal Cerita Matematika Topik Pecahan Ditinjau Dari Gender. JTAM (Jurnal Teori Dan Aplikasi Matematika), 2(2), 118-122.

Basiran. (2012). Faktor yang Mempengaruhi Kesulitan dalam Belajar. Jurnal Edukasi, 7(1), 1-18.

DePorter, B., \& Hernacki, M. (1999). Quantum Learning: membiasakan belajar nyaman dan menyenangkan (1st ed.). Kaifa.

Dila, O. R., \& Zanthy, L. S. (2020). Identifikasi Kesulitan Siswa Dalam Menyelesaikan Soal Aritmatika 
Sosial. Teorema: Teori Dan Riset Matematika, 5(1), 17. https://doi.org/10.25157/teorema.v5i1.3036

Elfiah, N. S., Maharani, H. R., \& Aminudin, M. (2020). Hambatan Epistemologi Siswa Dalam Menyelesaikan Masalah Bangun Ruang Sisi Datar. Delta: Jurnal Ilmiah Pendidikan Matematika, 8(1), 11-22. https://doi.org/10.31941/delta.v8i1.887

Ernawati, E., Hadaming, H., Ramdani, R., \& Ardhillah, A. (2019). Profil Kesulitan Mahasiswa dalam Menyelesaikan Soal Induksi Matematika Ditinjau dari Gaya Belajar. Delta-Pi: Jurnal Matematika Dan Pendidikan Matematika, 8(2), 14-22.

Inayah, F. F., Aliyah, M., Ulum, M., Sosial, A., \& Arithmetic, S. (2018). Penerapan teori situasi didaktik pada materi aritmatika sosial. KONTINU: Jurnal Penelitian Didaktik Matematika, 2(2), 35-47.

Indrawati, F. (2019). Hambata Dalam Pembelajaran Matematika. Simposium Nasional Ilmiah \& Call for Paper Unindra (Simponi), 62-69.

Insani, M. I., \& Kadarisma, G. (2020). Analisis Epistemological Obstacle Siswa Sma. JPMI (Jurnal Pembelajaran Matematika Inovatif), 3(5), 547-558. https://doi.org/10.22460/jpmi.v3i5.547-558

Maghfirah, Y., Rusnayati, H., \& Wijaya, A. F. C. (2017). Profil Hambatan Belajar Epistemologis Siswa Kelas VII SMP Terhadap Materi Energi dan Perubahannya Berbasis Analisis Tes Kemampuan Responden. Prosiding Seminar Nasional Fisika, 9-16. https://doi.org/10.21009/03.snf2017.01.oer.02 Maryanto, N. R., \& Siswanto, R. D. (2021). Analisis Kemampuan Berpikir Kreatif Matematis Ditinjau dari Gaya Kognitif dan Gender. ANARGYA: Jurnal Ilmiah Pendidikan Matematika, 4(1), 109-118.

Mulyati. (2015). Identifikasi Gaya Belajar Siswa Kelas V SD Se-Gugus 3 Kecamatan Pengasih Kabupaten Kulon Progo Tahun Ajaran 2014/2015. Universitas Negeri Yogyakarta.

Nuriza, I., Yusmin, E., \& Bistari, B. (2019). Analisis kesulitan siswa menyelesaikan soal cerita materi program linear berdasarkan gaya belajar siswa sma. Jurnal Pendidikan Dan Pembelajaran Khatulistiwa, 9(7), 1-9.

Peraturan Menteri Pendidikan dan Kebudayaan Republik Indonesia Nomor 103 tahun 2014 Tentang Pembelajaran pada Pendidikan Dasar dan Pendidikan Menengah. (2014).

Purwaningsih, D., \& Ardani, A. (2020). Kemampuan Pemecahan Masalah Matematis Materi Eksponen dan Logaritma Ditinjau dari Gaya Belajar dan Perbedaan Gender. AKSIOMA: Jurna Program Studi Pendidikan Matematika, 9(1), 118-125.

Rahmawati, D., \& Permata, L. D. (2018). Analisis Kesalahan Dalam Menyelesaikan Soal Cerita Progra Linear Dengan Prosedur Newman. Jurnal Elektronik Pembelajaran Matematika, 5(2), 173-185.

Rohimah, S. M. (2017). Analisis Learning Obstacle pada Materi Persamaan dan Pertidaksamaan Linear Satu Variabel. JPPM (Jurnal Penelitian Dan Pembelajaran Matematika), 10(1).

Siswanto, R. D. (2020). Analysis Epistemological Obstacle Students in Completing Mathematical Stories Based on Cognitive Styles. Innovation in Elementary Education, 6(1), 1-12.

Soleha, S., Rasiman, R., \& Purwosetiyono, F. D. (2019). Analisis Kesulitan Siswa dalam Menyelesaikan Masalah Matematika Ditinjau dari Gaya Belajar Siswa SMK. Imajiner: Jurnal Matematika Dan Pendidikan Matematika, 1(5), 138. https://doi.org/10.26877/imajiner.v1i5.4460 
Hambatan Epistemologi Peserta Didik dalam Menyelesaikan Aritmatika Sosial Berdasarkan Gaya Belajar dan Perbedaan Gender, Fauziah Ambar Parawansa, Rizki Dwi Siswanto

Sundayana, R. (2018). Kaitan antara Gaya Belajar, Kemandirian Belajar, dan Kemampuan Pemecahan Masalah Siswa SMP dalam Pelajaran Matematika. Mosharafa: Jurnal Pendidikan Matematika, 5(2), 75-84. https://doi.org/10.31980/mosharafa.v5i2.262 